\title{
20 Recommended Scholarly Readings
}

\section{Judson L. Jeffries ${ }^{1}$}

Published online: 14 August 2020

(C) Springer Science+Business Media, LLC, part of Springer Nature 2020

Abernethy, G. (2013). The iconography of Malcolm X. Lawrence, Kansas: University Press of Kansas.

Ambar, S. (2014). Malcolm X at Oxford Union: racial politics in a global era. England: Oxford University Press.

Baldwin, L. V. and Al-Hadid, A.Y. (2002). Between cross and crescent: Christian and Muslim perspectives on Malcolm and Martin. Gainesville, Florida. University Press of Florida.

Carew, J. (1994). Ghosts in our blood: with Malcolm X in Africa, England, and the Caribbean. Chicago, Illinois: Lawrence Hill Books.

Clarke, J. H. (ed.) (1969). Malcolm X: the man and his times. Trenton, New Jersey: Africa World Press.

Cone, J. (2012). Martin \& Malcolm \& America. New York, New York: Orbis.

Conyers, J. L. and A. Smallwood (eds). (2008). Malcolm X: a historical reader. Durham, NC: Carolina Academic Press.

Decaro, L. (1996). On the side of my people: a religious life of Malcolm X. New York, New York: Harper \& Row.

Goldman, P. (1973.). The death and life of Malcolm X. New York, New York: Harper \& Row.

Joseph, P. (2020). The sword and the shield: the revolutionary lives of Malcolm X and Martin Luther King Jr. New York, New York: Basic Books.

Lincoln, C. E. (1961). The black Muslims in America. Boston, Mass: Beacon Press.

Marable, M. (2011). Malcolm X: a life of reinvention. New York, New York: Viking. Perry, B. (1991). Malcolm: the life of a man who changed black America. Barrytown, New York: Station Hill.

Polizzi, D. (2019). A phenomenological hermeneutic of antiblack racism in the autobiography of Malcolm X. Lanham, Maryland: Lexington Books.

Roberts, R. and Smith, J. (2016). Blood brothers: the fatal friendship between Muhammad Ali and Malcolm X. New York, New York: Basic Books.

Judson L. Jeffries

jeffries.70@osu.edu

1 Department of African American and African Studies, The Ohio State University, Columbus, OH 43210, USA 
Sherwood, M. (2011). Malcolm X: visits abroad. Los Angeles, CA: Tsehai Publishers. Tuck, S. (2014). The night Malcolm X spoke at the Oxford Union. Berkeley, California: University of California Press.

Tyner, J. A. (2013). The geography of Malcolm X: black radicalism and the remaking of American space. New York, New York: Routledge.

Waldschmidt-Nelson, B. (2012). Dreams and nightmares: Martin Luther King Jr., Malcolm X, and the struggle for black equality in America. Gainesville, Florida: University Press of Florida.

Wood, J. (1992). Malcolm X: in our own image. New York: St. Martin’s Press.

Publisher's Note Springer Nature remains neutral with regard to jurisdictional claims in published maps and institutional affiliations. 